\title{
Evolution of Population Policy in Nepal
}

Govinda Prasad Adhikari (M. Phil.)*

\begin{abstract}
The evolution of population policy in Nepal has a history of about half century. This paper tries to discuss on the evolution of population policy discourse from the first five year plan to fifteenth five years plan. This study was based on descriptive as well as analytical in nature. Sources of information in this study are secondary in nature like published and unpublished research papers, national level report and journal's articles. Data are presented into tabular form and they are analyzed into descriptive form. Nepal has been following anti-natalist population policy to regulate fertility, mortality and migration from its first five year plan. The population policy of Nepal mainly shifted into three phases during the year 1950-2019. First, fertility regulating policy was focused during the year 1950-1980. Second, it was shifted into mortality regulating policy during the year 1980-2007 and finally, it is shifted into migration regulating policy since 2007 to still now. Nepal's population policy has made three major shifted during seventy year periods. There was major role of national and international conference of UN on population and major political changes of the country to give new direction of national population policy in Nepal.
\end{abstract}

Key words: Population policy, development plan, evolution \& reproductive health.

\section{Introduction}

Population policy can be defined as deliberately constructed or modified institutional arrangements or specific programs through the governments influence, directly or indirectly for the demographic change (Demeny, 2003). Davis (1970) has outlined the three features: action taken by government, cover population events and intention, and consequences of population of any population policy. The development of population policy may be affected by the global, national demographic trends accompanied by social, economic, cultural and political landscapes. On the other hands, history of world population was not uniform for all countries therefore every country should have their own population policy according to their needs.

*Mr. Adhikari is a Faculty Associate at the Department of Population Studies, Patan Multiple Campus, TU, Lalitpur, Nepal.Email:lachhugpa@yahoo.com 
In general, population policy can be used directly or indirectly. Direct population policy affects country's population size, structure and distribution directly where as indirect policie affect it indirectly. The responsive population policies are designed to manage population size where population influencing policies have direct interest for effecting population size, growth and distribution. Pro-natalist population policy encouraged to promote birth. Countries having low level of fertility rate (generally below the replacement level) are practicing pro-natalist population policies. Anti-natalist population policy encouraged to regulate or control birth. Countries with rapid population growth emphasized anti-natalist population policy.

Most of the developing countries have anti-natalist population policy. When a country has fewer people to support, there is a window of opportunity for rapid economic growth if the needs of young people are prioritized. There should be revised their population policy to get the window of opportunity. It occurs when the dependency ratio is smaller than the working age population. In case of Nepal, country's population age structure shows a relative young population. The young population is the ratio of people aged 15-59 years per one person aged 60 years and older in the population. In 1980, there were 16.8 working-age people per one old-age adult but in 2015, the potential support ratio has declined to 11.6 working-age people per one elderly person, the reduction was 33 percent in 35 years. This ratio was projected to decline at even faster rates. It was projected to be 5.6 working-age people per one elderly person in another 33 years (NPC, 2017).

\section{Population Related Programs and Policies in Nepal}

The initiation of population policies in Nepal was launched from its first five year plan (1956-61). During this period there was not any population focused policy was established but family planning association of Nepal was established. In the second plan (1963-65), concept of family planning was accepted in policy level. The first population policy was formally initiated during the third plan period (1965-70). Nepal Family Planning and Maternal Child Health Board were established under the Ministry of Health.

In 1974, at the time of first World Population Conference organized by the United Nations, the National Planning Commission (NPC) appointed a taskforce on population to develop a comprehensive population policy for the fifth year plan. That taskforce prepared a population policy document for Nepal. This policy document covered three components of population: fertility, mortality and migration. The fifth Five Year Plan (1975-80) adopted a few quantitative targets to reduce fertility and mortality rates. During this period, a vital registration system was introduced in some district as a pilot project. A population policy coordination board was constituted. Later this board was developed 
into National Commission on Population. During Sixth Plan (1980-85) Period, National Population Commission developed a National Population Strategy in 1983.

\section{National Population Strategy, 1983}

It was a foundation stage of initiating population policies in Nepal. This strategy contained both long term and short term targets. Major policy goals were to reduce the TFR per woman from 6.3 to 5.8 by the year 1985 , to 4.0 by the year 1990 and to 2.5 by the year 2000, although these targets were very ambitious and were never achieved (K.C. \& Acharya, 1993). The Seventh Plan (1985-90) brought a concept of unmet need for the contraception. To address this unmet need, a comprehensive policy was introduce in dealing with different issues like: women and development, child development, family planning and unmet need, population and development. The eights development plan (1992-97) continue with the integrated development approach taken in earlier plans (NPC, 1992 \& MoHP, 2012).

\section{Second Long Term Health Plan, 1997-2017}

The Ministry of Health and Population has developed a twenty year Second Long-Term Health Plan (SLTHP) for the period 1997-2017. The major aim of the SLTHP is to guide health sector development in the improvement of the health of the population; particularly those whose health needs are not often met. The aim of the SLTHP is to provide a guiding framework to build successive periodic and annual health plans that improve the health status of the population; to develop appropriate strategies, programmes, and action plans that reflect national health priorities that are affordable and consistent with available resources. It also focused to establish coordination among public, private and NGO sectors and development partners.

The Nine Development Plan 1997-2002 addressed the need of the Population Perspective Plan to manage population and reduce poverty. It focuses to reduce the total fertility rate to replacement, small family size and availability of FP/MCH services (NPC, 1998 and MoHP 2002). The Tenth Development Plan 2002-2007 covered poverty alleviation strategy in its objective (NPC, 2003). Second long term health plan (1997-20017) was formulated during tenth plan period. Major quantitative targets were set for period and most of these indicators were met by the year 2006. The three year interim development plan (2007/08-2010/11) was focused on family planning users, women of receiving maternal services from health worker.

Three year interim plan (2010/11-2012/13) focused on concept of small family size and 
quality population through the poverty alleviation and population management program. The main objective of that plan was to decrease the birth rate of Nepal to replacement level by 2022 .

Three year interim plan (2013/14-2015/16) emphasized on long term population policy. It focused to shift developing country to less developing by the year 2022. The main objective of this plan was to create an enabling environment for productive and quality of life of the people through population management.

The fourteenth plan (2016/17-2018/19) has focused on the balance between population dynamics, economic growth and social development through the population development. It also emphasizes on the management of internal migration and urbanization. Most of the programs, policies and targets are being aligned with Sustainable Development Goals (NPC, 2019).

\section{Population Perspective Plan, 2010-2031}

The Population Perspective Plan (PPP) has formulated based on multidisciplinary approach. It has initiated from the ten ${ }^{\text {th }}$ plan and set targets for the twenty year 20102031 period. The PPP has focused on integration population into all concerns areas of the development. The major objectives of PPP are: integration of population concerns in all area of development, facilitates rapid demographic transition through access to health care for poor/vulnerable groups, right based comprehensive reproductive health care, universal access to quality primary education, gender equality and empowerment of women, decentralized socio-economic development processes conductive to poverty alleviation and suggest implementation mechanisms and institutional arrangements for the effective coordination and monitoring of population programmes (MoHP, 2010).

The PPP identifies various population related themes to integrate population issues into development activities. The demographic analysis theme covers trend and differentials in demographic indicators of Nepal. Reproductive health theme focuses reproductive health as rights. Economic dimension includes the integration of population and development. It shows the implication of economic activities on population processes. The poverty dimension focused on poverty situation of Nepal. It attempts to establish the link between population and poverty. Spatial dimension emphasizes the issue of urbanization and migration of Nepal. The gender mainstreaming dimension focuses on the legal, institutional and socio-economic aspects of women. Social dimension focuses on the social and cultural aspects of Janajati and Dalit. Decentralization focuses on local level population management, its importance on population management and data 
collection at the local level. The Institutional mechanisms focus to monitor and evaluate the implemented population and development programmes (Aryal, 2014).

\section{Population Policy, 2071}

Nepal has made population policy by targeting 20 years program in 2071 . It focused on integration of population related elements into the sectoral development process at all levels for the sustainable development. The objectives of population policy are coordinate between population and development, develop sex and reproductive health, family planning services as right based approach, improve health services system for healthy life, improve internal and international migration and urbanization, integrate to gender equality and social equity, developed population data management system, study, research, survey and analysis and its usefulness and developed active population in more productive sector (MoHP, 2015).

Table-1: Quantitative targets for the year (2014-2034) plan

\begin{tabular}{|l|l|c|c|}
\hline S N & Indicators & Status in 2014 & Target for 2034 \\
\hline 1 & TFR (Per woman) & 23.0 & 2.1 \\
\hline 2 & Average population growth rate (In percent) & 1.35 & 1.1 \\
\hline 3 & CDR (Per 1000 population) & 7.0 & 5.0 \\
\hline 4 & IMR (Per 1000 live birth) & 33.0 & 25.0 \\
\hline 5 & Average life expectancy (In years) & 68.8 & 75.0 \\
\hline 6 & Average household size ( per HH) & 4.6 & 4.1 \\
\hline 7 & Absent population (In percent) & 7.3 & 5.0 \\
\hline 8 & Literacy rate (10 years and above) & 76.6 & 95.0 \\
\hline 9 & Availability of CPR (In percent) & 48.9 & 90.0 \\
\hline 10 & Urban population (In percent) & 17.0 & 60.0 \\
\hline
\end{tabular}

Source: MoHP, 2015

\section{The Fifteenth Development Plan (2076/77-2080/81)}

The National Planning Commission has prepared a preliminary draft of 15 th five-year development plan for fiscal year 2019- 20 to 2023-24. The15th five-year development plan has managed on the basis of 25 year vision paper. The 25 year plan has focused on the country's development vision and targets with the slogan of "Generating Prosperity and Happiness". The 25 year plan focuses the following quantitative targets. 
Table-2: Quantitative targets of 25 years master plan 2075-2100 years

\begin{tabular}{|l|c|c|}
\hline Targets & Status of 2074/75 & Target of 2100/01 \\
\hline Absolute poverty ( In percent) & 18.7 & 0 \\
\hline Multidimensional poverty ( In percent) & 28.6 & 5.0 \\
\hline Life expectancy at birth (Per year) & 69.7 & 80 \\
\hline Maternal mortality ratio (Per 1,00,000 live birth) & 239 & 20 \\
\hline Under five mortality rate (Per 1000) & 39.0 & 8.0 \\
\hline Literacy,15 years and above (In percent) & 58.0 & 96.0 \\
\hline Employment rate, 15 years and above (In percent) & 38.5 & 72.0 \\
\hline Un-employment rate ( In percent) & 11.4 & 3.0 \\
\hline Gender development index (GDI) & 0.925 & 1.0 \\
\hline Human development index (HDI) & 0.574 & 0.760 \\
\hline Basic social service attendance (In percent) & 17.0 & 100 \\
\hline
\end{tabular}

Source: NPC, 2019

Table-3: Institution development of the population

\begin{tabular}{|l|l|}
\hline Years & Institution of Population \\
\hline 1974 & Formed Task Force on Population Policy \\
\hline 1975 & Population Policy Coordination Board \\
\hline 1982 & National Commission on Population \\
\hline 1988 & Central Department of Population Studies (TU) \\
\hline 1990 & Population Division (Mahasakha) \\
\hline 1995 & Ministry of Population and Environment \\
\hline 2005 & $\begin{array}{l}\text { MOPE dissolved and its Population Division relocated in Ministry of Health which was } \\
\text { renamed Ministry of Health and Population }\end{array}$ \\
\hline 2010 & National Committee on Population Reformulated \\
\hline
\end{tabular}

\section{Discussion}

Development of population policy in Nepal has been influencing by national and international socio-economic and political events. The policy has been influenced by international conference. It also influences through major political changes of Nepal. These changes have positive impact into national development policy and population policy. The major political changes of Nepal in 1950s gave new insight into national development. Nepal had developed significance concept to change country's population 
through addressing fertility, mortality and migration concept in population. The first world population debate held in Rome in 1954 and the second conference held in Belgrade in 1965 that had focused on fertility and family planning. The Bucharest Conference (1974) and Mexico Conference (1984) emphasized on social and economic development for the solution of population problem. Therefore, most of the countries including Nepal focused anti-natalist population policy through controlling birth rate during 1950 s to $1980 \mathrm{~s}$.

The major political changes of 1990s gave new vision into national population development. Long term development concept on health and population was introduced in 1990s. First and second long term health and population policies were introduced during the eigh ${ }^{\text {th }}$ plan, nine ${ }^{\text {th }}$ plan and ten ${ }^{\text {th }}$ development plan. These policies in Nepal were formulated on the basis of ICPD (1994), Beijing (1995) and MDGs 2000. They all focused on reproductive health, gender equality, equity and empowerment. They also focused on population, sustained economic growth and sustainable development. Nepal has focused on population management policy through mortality reduction and migration regulation during 1990s to 2007. Nepal has developed various long term policies like 1983 National Health Strategy in 1983. The First Long Term Plan Health Plan in 1992 focused on lower fertility in replacement level. The Second Long Term Plan was to improve the health status of population of vulnerable group, women and children, the poor, underprivileged and marginalized groups. The Population Perspective Plan (PPP) was formulated based on a multidisciplinary approach to integrate economic and social sectors. These efforts were based to decreased fertility and mortality and population growth rate at replacement level.

After the people's movement 2006/07, Nepal entered into a new discourse like federal structure, issues of identity and social justice. National Population Policy 2072 was formulated from the guidance of Population Perspective Plan (PPP) that was grounded to integration of multi-sectored approach to develop the quality of population of Nepal. The Population Division of the Ministry of Health and Population launched the Local Leval Population Management Program (LLPM) from 2065/66 in 10 districts that have been implemented in all districts. The LLPM aims to raise awareness among local communities about population and reproductive health issues. It has also focused on ageing, safe migration, establishment of district population information centers, adolescents etc (Aryal,

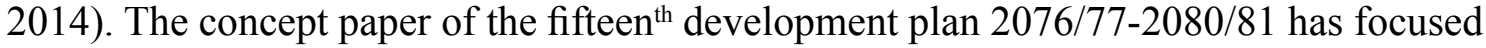
on the country's development plan with slogan "Generating Prosperity and Happiness" that includes various quantitative targets. It emphasized on quality improvement of population through population management. The goals and targets of SDGs 2016-2030 also focused on sustained development for quality of life of the people. 


\section{Conclusion}

The evolution of population policy discourse has covered seventy year long population policy issued of Nepal by using secondary sources information. Most of the developed countries have followed pro-natalist population policy and developing countries followed anti-natalist population policy. In the case of Nepal, anti-natalist population policy has used to regulate fertility from its first five year plan. The population policy of Nepal is mainly shifted into three phases during the year 1950-2019. First, fertility regulating policy was focused during the year 1950-1980. It focused the use of family planning to control the birth rate. The second shift was focused into mortality regulating policy during the year 1980-2007. It mainly focused into women and new born baby's health. Finally, the population policy of Nepal has shifted into migration regulating policy since 2007 to still now. Nepal has focused on population management policy through mortality reduction and migration regulation. The PPP has focused to the integration of multisectored approach to develop the quality of population of Nepal.

Nepal's population policy has made three major shifted during seventy year periods. Country's population policy was shifted by influencing of various national as well as international conference of United Nations on population issues. They have direct as well as indirect role to shape and reshape the national population policy of Nepal. On the other hand, major political changes of the country have supportive role to give new direction of national population policy. There was drastically change into population structure from high child population to young population since 1950's to 2020's. Therefore, the population policy of Nepal also shifted from population controlling policy through decreasing fertility and mortality rate to population management policy through quality improvement and migration of population.

\section{References}

Aryal, R. H. (2014). Population policy in the context of changing demographic picture of Nepal. Population monograph of Nepal, 2014, Vol. II. Kathmandu: National Planning Commission Secretariat and Central Bureau of Statistics, Nepal.

Davis, K. (1970). Population policy: Will current programmes succeed? Studies in Demography. London: George Allen and Unwin Ltd., United Kingdom. https://rvs.su/sites/default/ files/population_policy_-will_current_programs_succeed.pdf

Demeny, P. (2003). Population policy: A concise summary. New York: Population Council, United States.https://www.researchgate.net/publication/237380923_Population_Policy_A_ Concise_Summary 
K. C., B. K. \& Acharya, S. (1993). A review and revision of population policy in Nepal. Kathmandu: Central Department of Population Studies, Kirtipur, Nepal.

Ministry of Health and Population (MoHP). (2009). Action plan of population perspective plan 2010-2031. An Unpublished Document. Kathmandu: Ministry of Health and Population, Nepal.

Ministry of Health and Population (MoHP). (2010). Population perspective plan (PPP), 2010 2031. Kathmandu: Ministry of Health and Population, Nepal.

Ministry of Health and Population (MoHP). (2011). Nepal demographic and health survey 2012. Kathmandu: Ministry of Health and Population, New Era and Macro International Inc., Nepal.

Ministry of Health and Population (MoHP). (2014). Nepal population report, 2014. Kathmandu: Ministry of Health and Population, Nepal.

Ministry of Health and Population (MoHP). (2015). Population policy, 2014-2034. Kathmandu: Ministry of Health and Population, Nepal.

National Planning Commission (NPC). (1975). Fourth plan 1970-1975. Kathmandu: National Planning Commission Secretariat, His Majesty's Government of Nepal, Singh Durbar, Nepal.

National Planning Commission (NPC). (2017). Demographic changes of Nepal: Trends and policy implications. Kathmandu: National Planning Commission Secretariat, Government of Nepal, Singh Durbar, Nepal.

National Planning Commission (NPC). (2019). The concept paper of fifteenth plan, 2020/212025/26. Kathmandu: National Planning Commission Secretariat, Government of Nepal, Singh Durbar, Nepal. 